\author{
Lukasz PLESKACZ ${ }^{1}$ \\ Elżbieta FORNALIK-WAJS ${ }^{2}$ \\ Aleksandra ROSZKO'
}

\title{
VELOCITY AND TEMPERATURE MALDISTRIBUTION DUE TO THE MAGNETIC FIELD INFLUENCE
}

\begin{abstract}
The elements that possess the ability of changing the flow structure (neckings, nozzles, valves, elbows) can be found in numerous industrial and medical applications. This ability leads to the velocity and temperature fields modification and can be a reason of negative effects like pressure loss. These negative effects can be reduced by the usage of magnetic field. Magnetic control of weakly magnetic fluids' velocity and temperature distributions is well known. Presented paper considers the numerical analysis of velocity and temperature maldistribution due to the influence of strong magnetic field. The analysis was carried out for threedimensional circular duct with simplified stenosis (narrowing of the blood vessels), which took form of confusor-diffuser section of the pipe. The system included duct and the magnetic coil that was oriented perpendicularly to the flow axis and placed in between confusor and diffuser. The wall of the stenosis was divided into subzones partially heated in order to control the velocity and temperature fields. Biot-Savart's law was applied to calculate the distribution of the magnetic field, which was then used to obtain the magnetic force distribution and added to principle of conservation of momentum equations as the external body force. Commercially available software Ansys Fluent 13 was chosen to conduct the numerical analysis, however special user-defined modulus to calculate the distribution of magnetic force was prepared and implemented in it. The results pointed out that the usage of magnetic field might provide a significant change in both velocity and temperature distribution, especially for low Reynolds number flows.
\end{abstract}

Keywords: forced convection, numerical fluid mechanics, magnetic field, magnetic force

\footnotetext{
${ }^{1}$ Autor do korespondencji/corresponding author: Łukasz Pleskacz, AGH University of Science and Technology, Mickiewicza 30, 30-059 Kraków, pleskacz@agh.edu.pl.

${ }^{2}$ AGH University of Science and Technology, Kraków.
} 


\section{Introduction}

The systems of channels or pipes can be found everywhere. Usually they contain additional elements like nozzles, valves, elbows, etc., which have had an influence on the secondary flows. One of the bio-engineering problems is analysis of blood flow in vanes with stenosis, some of the papers discussed it [2, 7]. The negative effects of stenosed vanes or narrowed channels can be tried to be reduced with application of magnetic field. Numerous papers described control of thermal convection by the strong magnetic field $[1,3,8,9]$. It was possible because the magnetic buoyancy force was much stronger than the gravitational buoyancy force. Therefore, the magnetic field was able to determine convective flow. More complex phenomenon is in the case of forced convection and the magnetic field influence on it. There is limited number of publications considering this problem. The magnetic field influence on the blood flow was presented in $[5,6]$. They analyzed the isothermal conditions and the magnetic field influence on the flow of electro-conducting fluid. Therefore, the main role was played by the Lorentz force. The problem concentrated on drug deliver particles targeting with utilization of magnetic field.

In the frame of this paper the analysis of magnetic field influence on the non-isothermal and non-electro-conducting fluid flow the contractingexpanding pipe is presented. The main aim is to investigate if the magnetic field can change the secondary flow. Control of the flow behind the magnetic coil can prevent fouling or narrowing the channel. Therefore, it is important from engineering and bio-engineering points of view.

\section{Mathematical model}

In this section the governing equations used as a base for further numerical formulations are presented. For isothermal flow analysis the mathematical model consisted of the continuity and momentum equations. When the heat transfer was present in the flow, the energy conservation equation supplemented the model. Considering the influence of magnetic field on the flow the distribution of magnetic induction had to be known, therefore Biot-Savart's law complemented the mathematical model.

The following equation represents the continuity equation with basic assumptions including: incompressible flow, lack of additional mass source, stationary, laminar, three-dimensional flow:

$$
\frac{\partial}{\partial x} u_{x}+\frac{\partial}{\partial y} u_{y}+\frac{\partial}{\partial z} u_{z}=0
$$

where: $u_{x}, u_{y}, u_{z}-$ velocity components $\mathrm{m} / \mathrm{s}$. 
Considering above mentioned conditions complemented with the gravitational and magnetic forces (7) treated as the external body forces led to the set of momentum equations as follows:

$$
\begin{aligned}
& \rho\left(u_{x} \frac{\partial u_{x}}{\partial x}+u_{y} \frac{\partial u_{x}}{\partial y}+u_{z} \frac{\partial u_{x}}{\partial z}\right)=-\frac{\partial p}{\partial x}+\mu\left(\frac{\partial^{2} u_{x}}{\partial x^{2}}+\frac{\partial^{2} u_{x}}{\partial y^{2}}+\frac{\partial^{2} u_{x}}{\partial z^{2}}\right)+F_{\text {magx }} \\
& \rho\left(u_{x} \frac{\partial u_{y}}{\partial x}+u_{y} \frac{\partial u_{y}}{\partial y}+u_{z} \frac{\partial u_{y}}{\partial z}\right)=-\frac{\partial p}{\partial y}+\mu\left(\frac{\partial^{2} u_{y}}{\partial x^{2}}+\frac{\partial^{2} u_{y}}{\partial y^{2}}+\frac{\partial^{2} u_{y}}{\partial z^{2}}\right)+ \\
& +\rho g+F_{\text {magy }}, \\
& \rho\left(u_{x} \frac{\partial u_{z}}{\partial x}+u_{y} \frac{\partial u_{z}}{\partial y}+u_{z} \frac{\partial u_{z}}{\partial z}\right)=-\frac{\partial p}{\partial z}+\mu\left(\frac{\partial^{2} u_{z}}{\partial x^{2}}+\frac{\partial^{2} u_{z}}{\partial y^{2}}+\frac{\partial^{2} u_{z}}{\partial z^{2}}\right)+F_{\text {magz }}
\end{aligned}
$$

where: $\rho$ - density $\mathrm{kg} / \mathrm{m}^{3}, \mu$-dynamic viscosity Pa.s, $g$ - gravitational acceleration $\mathrm{m} / \mathrm{s}^{2}, F_{\text {mag }}$ - magnetic force $\mathrm{N} / \mathrm{m}^{3}$.

The oncoming formula describes energy equation with following assumptions: the viscous dissipation and species diffusion are negligible, flow is steady, there is lack of external heat source:

$$
u_{x} \frac{\partial T}{\partial x}+u_{y} \frac{\partial T}{\partial y}+u_{z} \frac{\partial T}{\partial z}=\frac{\lambda}{\rho c_{p}}\left(\frac{\partial^{2} T}{\partial x^{2}}+\frac{\partial^{2} T}{\partial y^{2}}+\frac{\partial^{2} T}{\partial z^{2}}\right)
$$

where: $T$ - temperature $\mathrm{K}, \lambda$ - thermal conductivity $\mathrm{W} /(\mathrm{m} \cdot \mathrm{K}), c_{p}$ - specific heat $\mathrm{J} /(\mathrm{kg} \cdot \mathrm{K})$.

Biot-Savart's law was applied in order to calculate the distribution of magnetic field induction around single circular coil [4]:

$$
\vec{B}=\frac{\mu_{m} i}{4 \pi} \int_{c} \frac{d \vec{s} \times \vec{r}}{|r|^{3}}
$$

where: $\vec{B}$ - magnetic induction vector $\mathrm{T}, \mu_{m}$ - magnetic permeability $\mathrm{H} / \mathrm{m}, i-$ electrical current A, $d \vec{s}$ - infinitely small element of the coil $\mathrm{m}, r$ - radius of coil $\mathrm{m}, \vec{r}$ - position vector $\mathrm{m}$.

Locating studied flows in the magnetic field affects the fluid with a new kind of influence, known as the magnetic force. This force was included in the momentum conservation equation as the external body force in the following form [1]: 


$$
\vec{F}_{\text {mag }}=-\left(1+\frac{1}{T_{0} \beta}\right) \frac{\chi \beta\left(T-T_{0}\right)}{2 \mu_{m}} \vec{\nabla} B^{2},
$$

where: $T_{0}=\left(T_{w}+T_{f}\right) / 2$ - reference temperature $\mathrm{K}, T_{w}$ - heated wall temperature $\mathrm{K}, T_{f}$ - inlet fluid temperature $\mathrm{K}, \beta$ - thermal expansion coefficient $\mathrm{K}^{-1}, \chi$ - volumetric magnetic susceptibility.

\section{Studied cases and applied solutions}

Figure 1 presents the pipe with simplified stenosis which took form of confusor-diffuser section of the pipe. The inlet and outlet diameter of the pipe was of $d_{s l}=0.01 \mathrm{~m}$. The duct began with inlet of a length $l_{i s}=0.05 \mathrm{~m}$ and then started to narrow on a length $l_{s}=0.015 \mathrm{~m}$ to the minimal diameter of $d_{s 2}=0.005$ $\mathrm{m}$. From this point the pipe widened itself to obtain inlet diameter and ended with straight outlet of a length of $l_{o s}=0.1 \mathrm{~m}$. The magnetic coil was oriented perpendicularly to the flow axis and placed in between of confusor and diffuser parts. The diameter of coil was twice that of a pipe at inlet or outlet. The wall at confusor-diffuser section was divided into four subzones, which gave four basic variants of isothermal heating in this area. The parabolic velocity profile was assumed at the inlet with average inlet velocity of $U_{\text {avg }}=0.023 \mathrm{~m} / \mathrm{s}(\operatorname{Re}=16)$. The inlet fluid temperature was $T_{f}=300 \mathrm{~K}$ and the temperature of the heated wall was $T_{w}=310 \mathrm{~K}$. The magnetic induction in the centre of coil was $b_{0}=10$ $\mathrm{T}$. At the outlet the pressure was assumed to be $p_{o}=101325 \mathrm{~Pa}$.

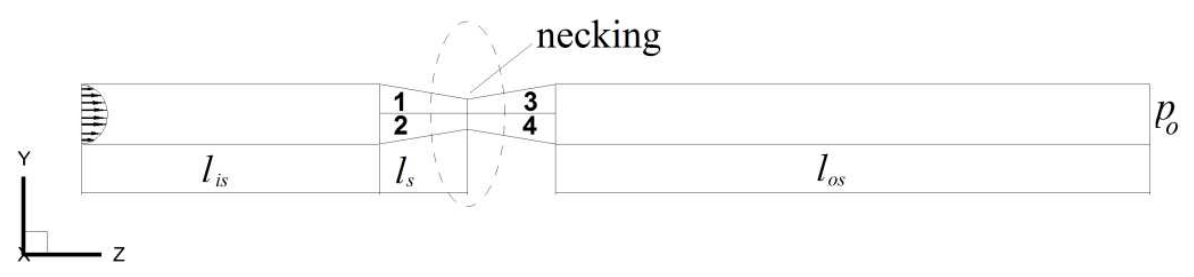

Fig. 1 The schematic view of geometry and boundary conditions.

The grid generation and numerical computations were performed with the usage of commercially available software (GAMBIT 2.3 and Ansys Fluent 13). The grid was unstructured and contained 185430 elements. The special userdefined functions written by the Authors were implemented into the software to calculate three-dimensional parabolic velocity profile and the distribution of the magnetic force. The results for heating subzones pairs (see figure 1) of 1-2 (variant 1 and 2) and 3-4 (variant 3 and 4) showed symmetry with respect to the pipe axis, therefore they can be limited to the one of the pair. Table 1 lists the thermophysical and magnetic properties of the used working fluid (air). 
Table 1. Thermophysical and magnetic properties of air

\begin{tabular}{|c|c|c|c|l|l|l|}
\hline Density & $\begin{array}{l}\text { Dynamic } \\
\text { viscosity }\end{array}$ & $\begin{array}{l}\text { Volumetric } \\
\text { thermal } \\
\text { expansion } \\
\text { coefficient }\end{array}$ & $\begin{array}{l}\text { Magnetic } \\
\text { susceptibility }\end{array}$ & $\begin{array}{l}\text { Magnetic } \\
\text { permeabi- } \\
\text { lity }\end{array}$ & $\begin{array}{l}\text { Specific } \\
\text { heat }\end{array}$ & $\begin{array}{l}\text { Thermal } \\
\text { conductivity }\end{array}$ \\
\hline$\rho \mathrm{kg} / \mathrm{m}^{3}$ & $\mu \mathrm{Pa} \cdot \mathrm{s}$ & $\beta \mathrm{K}^{-1}$ & $\chi-$ & $\mu_{m} \mathrm{H} / \mathrm{m}$ & $c_{p} \mathrm{~J} /(\mathrm{kg} \cdot \mathrm{K})$ & $\lambda \mathrm{W} /(\mathrm{m} \cdot \mathrm{K})$ \\
\hline 1.225 & $1.7894 \cdot 10^{-5}$ & $3.33 \cdot 10^{-3}$ & $3.77 \cdot 10^{-7}$ & $4 \pi \cdot 10^{-7}$ & 1006.43 & $2.42 \cdot 10^{-2}$ \\
\hline
\end{tabular}

\section{Results and discussion}

In figure 2 the distributions of velocity and temperature for the flow without magnetic field are presented. The velocity distributions are identical, despite of different temperature distributions.

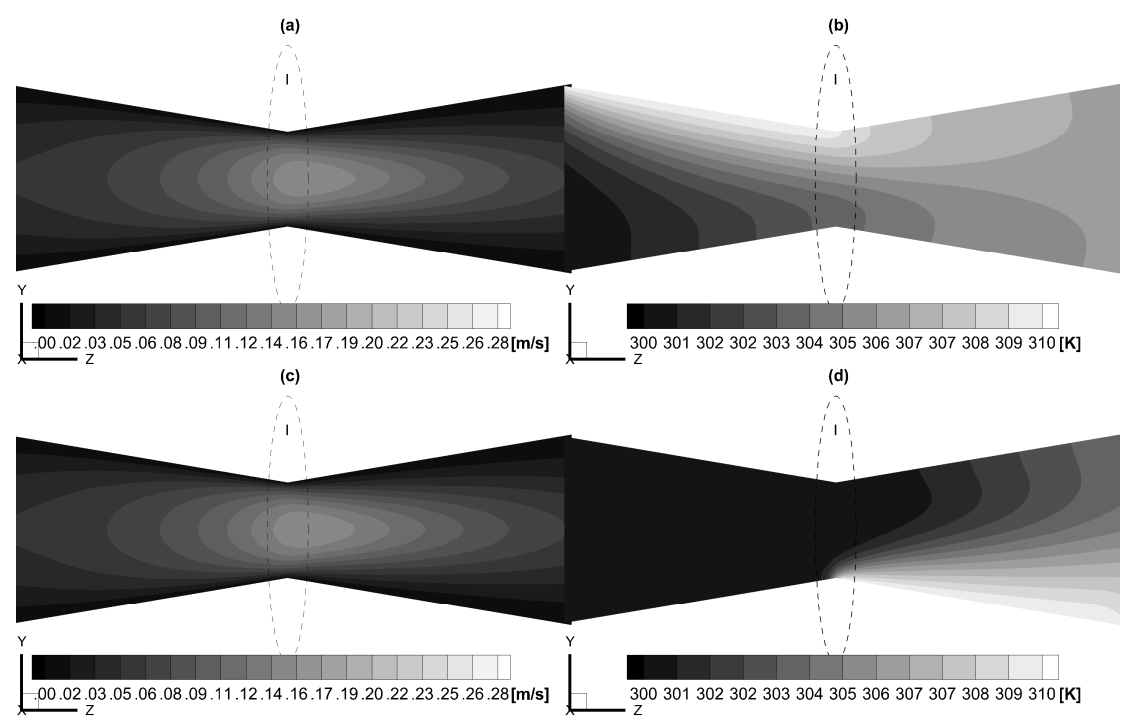

Fig. 2 Velocity and temperature distributions for the flow without magnetic field: (a) velocity contours for variant 1 , (b) temperature contours for variant 1 , (c) velocity contours for variant 4 , (d) temperature contours for variant 4 .

Figures 3 and 4 present distributions of selected flow characteristics. In the case of wall heated before the necking (figure 3 (a)) and after it (figure 4 (a)) the characteristic deflection of the flow's direction could be observed. In the case of variant 1 (and variant 2 according to relation described before) repulsion of fluid from the heated wall took place. For variant 4 (and respectively 3 ) attraction towards the heated wall was observed. However, in the case of variant 1 deformation of the flow structure spread out over whole studied area, while in the case of variant 4 deformation started just behind the necking. For the variant 
1 a large recirculation zone near the heated wall could be found. After the necking flow suppression area appeared. It was placed symmetrically in regard to the coordinates system origin (centre of magnetic coil). The similar area was observed in the case of variant 4 near the non-heated wall (wall number 3 ). The heating of the wall before the necking caused significant increase of the flow velocity (two-times bigger than the maximal velocity obtained in the case of the flow without magnetic field) and also replacement of the highest velocity zone to the area before the necking. In the case of variant 4 acceleration of the fluid was also observed. Nevertheless, it was very subtle. In this case the magnetic force influenced the shape and size of the highest velocity zone.

Relatively low temperature gradient (figures 3 (b) and 4 (b)) allows precise localization of isotherm $T_{0}=305 \mathrm{~K}$. It is known from the equation (7) that the sign of the magnetic force magnitude depends on the difference between the local temperature and reference temperature $T_{0}$ (that is arithmetic mean between the fluid temperature at the inlet $T_{f}$ and the heated wall temperature $T_{w}$ ). Thus, the temperature distribution might be divided in two subzones varing in magnetic force direction. The fluid with temperature below the reference temperature is attracted to the magnetic coil, while the fluid with temperature above the reference temperature is repulsed from it. The surface separating these two subzones is isotherm $T_{0}$. It is clearly visible in figures 3 (c) and 4 (c) in the form of sudden drop of magnetic force magnitude.

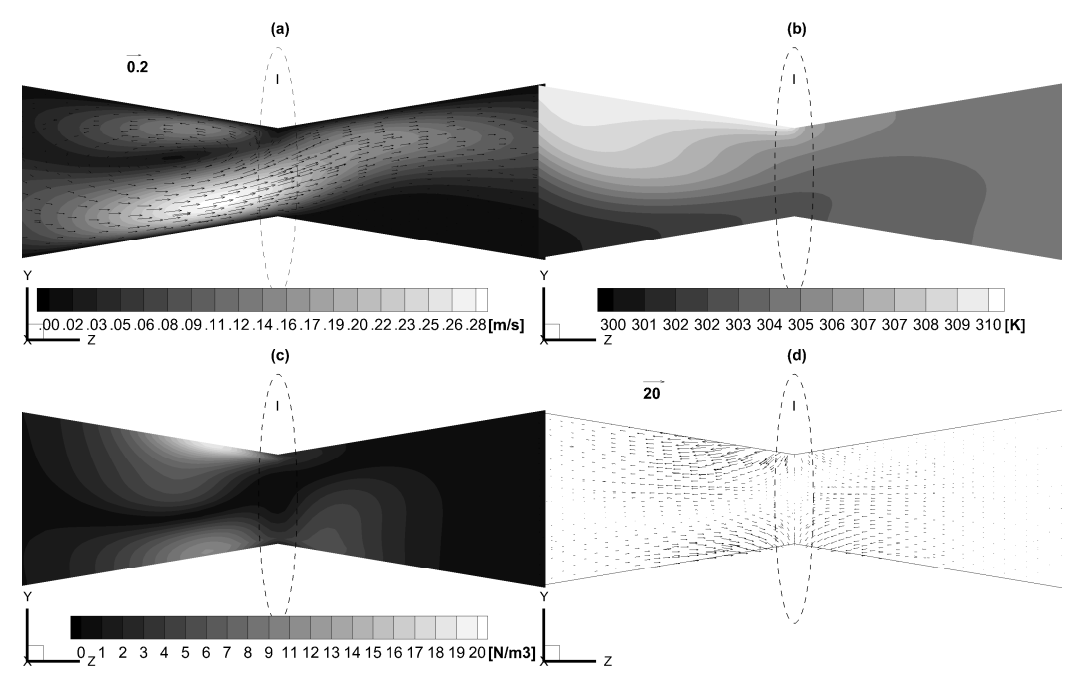

Fig. 3 Flow characteristics for variant 1: (a) velocity contours and vectors, (b) temperature contours, (c) magnetic force contours, (d) magnetic force vectors. 


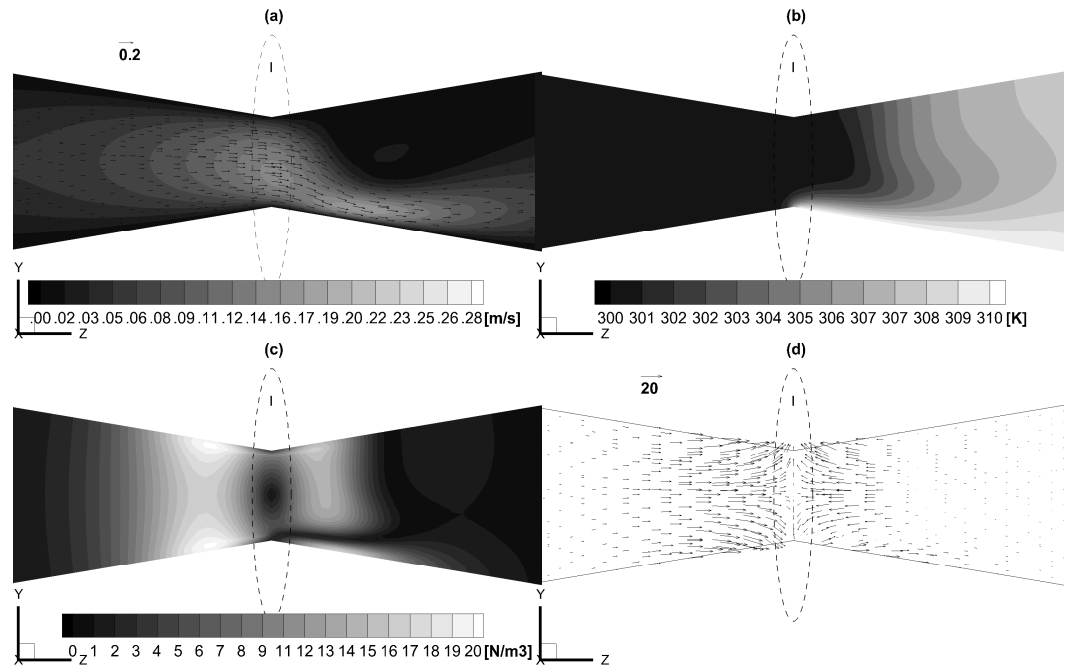

Fig. 4 Flow charactersistics for variant 4: (a) velocity contours and vectors, (b) temperature contours, (c) magnetic force contours, (d) magnetic force vectors

In figures 3(d) and 4(d) the magnetic force vectors are presented. They showed that for variant 1 the magnetic force was acting in the direction opposite to the basic flow. Due to that the recirculation zone appeared. The magnetic force decay near the wall number 3 caused deflection of the flow towards it in the area after the necking. The turn in magnetic force direction in variant 4 led to the acting of it accordingly to the basic flow direction and it is was a reason for acceleration of the fluid in this area. Near the wall number 3 the magnetic force acted in the opposite direction, which caused the stoppage of the flow.

\section{Conclusions}

In this paper the numerical analysis of magnetic field influence on the low Reynolds number flow was presented. In dependence on the heating zone of contracting-expanding pipe significant change in the velocity and temperature fields could be observed. Due to the magnetic buoyancy force the direction of fluid flow was modified and moreover the fluid stream was twisted. The direction of changes depended on the heated zone. These velocity and temperature maldistributions can prevent fouling.

\section{References}

[1] Bednarz T., Fornalik E., Tagawa T., Ozoe H., Szmyd J.S.: Experimental and numerical analyses of magnetic convection of paramagnetic fluid in a cube heated and cooled from opposing verticals walls, Int. J. Thermal Sci., 44 (2005) 933-943. 
[2] Chakravarty S., Datta A., Mandal P.K.: Analysis of nonlinear blood flow in a stenosed flexible artery, Int. J. Eng. Sci., 33 (1995) 1821-1837.

[3] Filar P.: Convection of paramagnetic fluid in a cylindrical enclosure under a strong magnetic field, Ph.D. Thesis, Kyushu University 2004.

[4] Jackson J.D.: Classical Electrodynamics, John Wiley \& Sons, Inc., New York 1998.

[5] Kenjereš S.: Numerical analysis of blood flow in realistic arteries subjected to strong non-uniform magnetic fields, Int. J. Heat Fluid Flow, 29 (2008) 752-764.

[6] Kenjereš S. and Righolt B.W.: Simulation of magnetic capturing of drug carriers in the brain vascular system, Int. J. Heat Fluid Flow, 35 (2012) 68-75.

[7] Misra J.C. and Shit G.C.: Blood flow through arteries in a pathological state: A theoretical study, Int. J. Eng. Sci., 44 (2006) 662-671.

[8] Ozoe H.: Magnetic Convection, Imperial College Press, London 2005.

[9] Wróbel W., Fornalik-Wajs E., Szmyd J.S.: Experimental and numerical analysis of thermo-magnetic convection in a vertical annular enclosure, Int. J. Heat Fluid Flow, 31 (2010) 1019-1031.

\section{ZMIANA ROZKŁADÓW PRĘDKOŚCI I TEMPERATURY POD WPLYWEM POLA MAGNETYCZNEGO}

\section{Streszczenie}

Elementy posiadające zdolność zmiany struktury przepływu (przewężenia, dysze, zawory, kolanka) mają wiele zastosowań w przemyśle i medycynie. Zdolność ta prowadzi do modyfikacji pól temperatury oraz prędkości i może być przyczyną negatywnych efektów, takich jak straty ciśnienia. Te negatywne efekty można wyeliminować przy użyciu pola magnetycznego. Magnetyczna kontrola rozkładów prędkości i temperatury słabo namagnesowanych cieczy jest dobrze znana. Niniejszy artykuł prezentuje analizę numeryczną zaburzeń pól prędkości i temperatury pod wpływem silnego pola magnetycznego. Analizę przeprowadzono dla trójwymiarowych kanałów o przekroju okrągłym z uproszczoną stenozą (zwężeniem naczyń krwionośnych) w formie połączenia typu konfuzor-dyfuzor. Badany układ składał się z kanału oraz cewki magnetycznej zorientowanej prostopadle do osi przepływu i umieszczonej między konfuzorem a dyfuzorem. Ścianka stenozy została podzielona na mniejsze obszary grzane różnicowo, aby odpowiednio zmieniać pole temperatury i prędkości. Zastosowano prawo Biota-Savarta w celu obliczenia rozkładu indukcji pola magnetycznego, który później został wykorzystany do otrzymania rozkładu siły magnetycznej. Siła ta została umieszczona w równaniach zachowania pędu. Analizę przeprowadzono przy użyciu komercyjnego oprogramowania (Ansys Fluent 13), w którym zaimplementowano specjalną funkcję definiowaną przez użytkownika w celu obliczenia rozkładu indukcji oraz siły magnetycznej. Wyniki wykazały, że pole magnetyczne może mieć znaczący wpływ na rozkłady prędkości i temperatury, szczególnie w przypadku przepływów o niskiej liczbie Reynoldsa.

Keywords: konwekcja wymuszona, numeryczna mechanika płynów, pole magnetyczne, siła magnetyczna

DOI: $10.7862 / \mathrm{rm} .2014 .47$

Otrzymano/received: 25.05 .2014

Zaakceptowano/accepted: 28.06.2014 